\title{
EFFECT OF OZONE TREATMENT ON THREE BACTERIAL STRAINS OF DRINKING WATER
}

\author{
Mariana Ferdes, Bianca-Stefania Zabava, Mirela-Nicoleta Dinca, Gigel Paraschiv \\ University Politehnica of Bucharest, Romania \\ marianaferdes@yahoo.com, bianca.dragoiu@yahoo.com,mirela_dilea@yahoo.com, \\ paraschiv2005@yahoo.com
}

\begin{abstract}
Because of its excellent disinfection and oxidation qualities, ozone is widely used for drinking water treatment. Ozone is frequently used to destroy and inhibit the growth of microorganisms from contaminated water. In this paper, ozone efficiency was tested for water treatment containing cell suspensions of Escherichia coli K12-MG 1655, Enterococcus faecalis ATCC 29212 and Pseudomonas aeruginosa ATCC 9027 using an ozone generator OZONFIX 8G. Water samples were subjected to ozone treatment for different periods, ranging from 15 seconds to 15 minutes. Ozone was generated by the corona discharge method. The use of electrical power to generate ozone by corona discharge is the most commercially viable method. Analyses were performed both for determining the cell viability by the total plate count technique, and for determination of the cell growth curves after the applied ozone treatment. The bacteria were cultured in liquid media on an orbital shaker at 150 $\mathrm{rpm}$ and $37^{\circ} \mathrm{C}$. The bacterial multiplication was measured by recording the absorbance $\mathrm{A}_{600 \mathrm{~nm}}$ on a UV-VIS spectrophotometer. Following the experiments, it was found that ozone showed a strong effect of inhibiting the growth of the three bacterial strains, both in terms of viability and multiplication capacity. The most resistant was the bacterial strain of Pseudomonas aeruginosa ATCC 9027.
\end{abstract}

Keywords: ozone treatment, bacterial strains, growth.

\section{Introduction}

Human exposure to wastewater discharged into the environment has increased within the past 15 to 20 years with the rise in population and the greater demand for water resources for recreation and other purposes. The organisms of concern in domestic wastewater include enteric bacteria, viruses, and protozoan cysts [1]. Disinfection is considered to be the primary mechanism for the inactivation/destruction of pathogenic organisms to prevent the spread of waterborne diseases to downstream users and the environment. The disinfecting process has been considered as one of the most important steps in drinking water treatment and improper attention to this process can cause a social disaster [2].

An excellent disinfectant of drinking water is ozone. This is able to inactivate even more resistant pathogenic microorganisms such as Escherichia coli, Enterococcus faecalis and Pseudomonas aeruginosa, along with the conventional disinfectants (chlorine, chlorine dioxide). Ozone has been applied for water disinfection purposes for almost a century. A recent survey in Switzerland among water works that apply ozone has shown that for $90 \%$ of these plants the main reason for its application is disinfection [3].

Ozonation represents an alternative to chlorination in drinking-water disinfection, which was done first a century ago and has become an established means of disinfection [4; 5]. Bacteria, including Escherichia coli, Staphylococcus aureus, Bacillus cereus, Bacillus megaterium, Salmonella typhimurium, Shigella flexneri, and Vibrio cholerae are sensitive to ozonated water under various conditions [6].

It was found that the cost of ozone disinfection systems is dependent on the manufacturer, the site, the capacity of the plant, and the characteristics of the wastewater to be disinfected. Ozonation costs are generally high in comparison with other disinfection techniques. In 2005, Nabi Bidhendi et al. have developed a study that explains the opportunities and threats to the drinking water ozonation process [2]. Prabakaran M. et colab. have analyzed ozone treatment by applying to human pathogenic bacteria such as Escherichia coli and Pseudomonas fluorescens, Salmonella typhi and Klebsiella pneumoniae. Among the treated bacterial species, E.coli revealed high sensitivity to ozone treatment compared to other bacterial strains [7].

The aim of this paper was to evaluate the ozone efficiency for water treatment containing cell suspensions of Escherichia coli K12-MG 1655, Enterococcus faecalis ATCC 29212 and Pseudomonas aeruginosa ATCC 9027 using an ozone generator OZONFIX 8G. 


\section{Materials and methods}

\section{Bacterial strains}

Three strains of bacterial species commonly found in water were used: Escherichia coli K12-MG 1655, Pseudomonas aeruginosa ATCC 9027 and Enterococcus faecalis ATCC 29212. The bacterial strains were cultivated in tubes on Nutrient Agar medium (Merck) with the following composition: peptone from meat $5.0 \mathrm{~g} \mathrm{~L}^{-1}$, meat extract $3.0 \mathrm{~g} \mathrm{~L}^{-1}$, agar-agar $12.0 \mathrm{~g} \mathrm{~L}^{-1}, \mathrm{pH} 7.0$, and kept at $4{ }^{\circ} \mathrm{C}$ until use. The viability of bacteria after ozone treatment was evaluated by the conventional total plate count method on Plate Count Agar medium. The bacterial growth behaviour was assessed by cultivation in liquid media on a rotary incubator (Thermoshake, Gerhardt), at $150 \mathrm{rpm}, 37{ }^{\circ} \mathrm{C}$, for 26 hours. The absorbances of bacterial cultures were measured at $600 \mathrm{~nm}$ using the T92+UV VIS spectrophotometer, PG Instruments.

\section{Ozone equipment}

Ozone was produced by an ozone generator type OZONFIX 8G commercially available, with a production of 8 grams of pure ozone per hour and a flow rate of $2.5 \mathrm{~L} \mathrm{~min}^{-1}$. The equipment produces ozone by corona discharge. The gas was sterilized with a sterile air filter and was bubbled through a ceramic frit $(3 \mathrm{~cm} \times 1.8 \mathrm{~cm})$ in a volume of $200 \mathrm{~mL}$ of bacterial cells suspension in sterile water.

\section{Methods}

$10 \mathrm{~mL}$ of bacterial cells suspension from 48 hours old cultures on Nutrient Agar medium in tubes were used to inoculate $200 \mathrm{~mL}$ liquid media (mentioned below) in $500 \mathrm{~mL}$ Erlenmeyer flasks. E. coli was grown in Luria Bertani (Merck) liquid medium (triptone $10 \mathrm{~g} \mathrm{~L}^{-1}$, yeast extract $5 \mathrm{~g} \mathrm{~L}^{-1}, \mathrm{NaCl} 5 \mathrm{~g}$ $\mathrm{L}^{-1}$ ), E. faecalis and P. aeruginosa in Nutrient Broth (Merck) medium (peptone from meat $5.0 \mathrm{~g} \mathrm{~L}^{-1}$, meat extract $3.0 \mathrm{~g} \mathrm{~L}^{-1}$ ). The cultures were incubated at $37{ }^{\circ} \mathrm{C}$, for 24 hours on an orbital incubator at $150 \mathrm{rpm} .0 .1 \mathrm{~mL}$ of each bacterial culture was used to prepare the cell suspension to be treated with ozone. At time intervals of $15 \mathrm{sec}, 30 \mathrm{sec}, 1 \mathrm{~min}, 1 \mathrm{~min} 30 \mathrm{sec}, 2 \mathrm{~min}, 2 \mathrm{~min} 30 \mathrm{sec}, 3 \mathrm{~min}, 5 \mathrm{~min}, 10$ min, $15 \mathrm{~min}$, samples of $1 \mathrm{~mL}$ were taken for total plate count determination. The dilution of each sample and the addition of agar medium have been made as quickly as possible, because the interaction of RONS (reactive oxygen and nitrogen species) produced in the ozone generator with bacterial cells was very strong. At the same time, another volume of $1 \mathrm{~mL}$ of ozonized cell suspension was taken for inoculation of liquid media in Erlenmeyer flasks. Petri dishes were incubated at $37{ }^{\circ} \mathrm{C}$ for 48 hours and the number of viable cells was determined. The samples from Erlenmeyer cultures were analyzed during 26 hours of incubation. All samples were performed in triplicate.

\section{Results and discussion}

The three tested bacteria, known as potentially dangerous for health, if they are present in large number in water, can be destroyed through ozone treatment. The results of sensitivity of E.coli K12MG 1655, E. faecalis ATCC 29212 and P. aeruginosa ATCC 9027, evaluated by plate count technique are presented in Table 1 . The values of ufc $\mathrm{mL}^{-1}$ for all bacterial species after ozonation at different times, compared to the untreated reference sample, showed a very large difference. After only 15 seconds the viability decreased by about three orders of magnitude for all species. After 30 seconds, only a few colonies have grown on culture media. Keeping the bacterial cells in ozone bubbling water for more than 1 minute, caused irreversible damage and cell death.

Table 1

Results of sensitivity evaluated by plate count technique

\begin{tabular}{|c|c|c|c|}
\hline Strain/Time & $\begin{array}{c}\text { E. coli } \mathrm{K12}-\mathrm{MG} \\
1655, \mathrm{ufc}^{-\mathrm{ml}^{-1}}\end{array}$ & $\begin{array}{c}\text { E. faecalis ATCC } \\
29212, \text { ufc}^{2} \mathrm{ml}^{-1}\end{array}$ & $\begin{array}{c}\text { P. aeruginosa ATCC } \\
9027, \text { ufc } \mathrm{ml}^{-1}\end{array}$ \\
\hline 0 & $62 \times 10 * 4$ & $22 \times 10 * 4$ & $31 \times 10 * 4$ \\
\hline $15 \mathrm{sec}$ & 280 & 120 & 650 \\
\hline $30 \mathrm{sec}$ & 24 & 5 & 59 \\
\hline $1 \mathrm{~min}$ & 0 & 0 & 0 \\
\hline $1 \mathrm{~min} 30 \mathrm{sec}$ & 0 & 0 & 0 \\
\hline
\end{tabular}

For ozonation times longer than 1 minute, the number of ufc $\mathrm{mL}^{-1}$ was zero. 
The growth kinetics of the tested bacterial strains have been examined through measurement of absorbance at $600 \mathrm{~nm}$ in cultures incubated on an orbital shaker, for 26 hours. The obtained results are shown in Figure 1.

a)

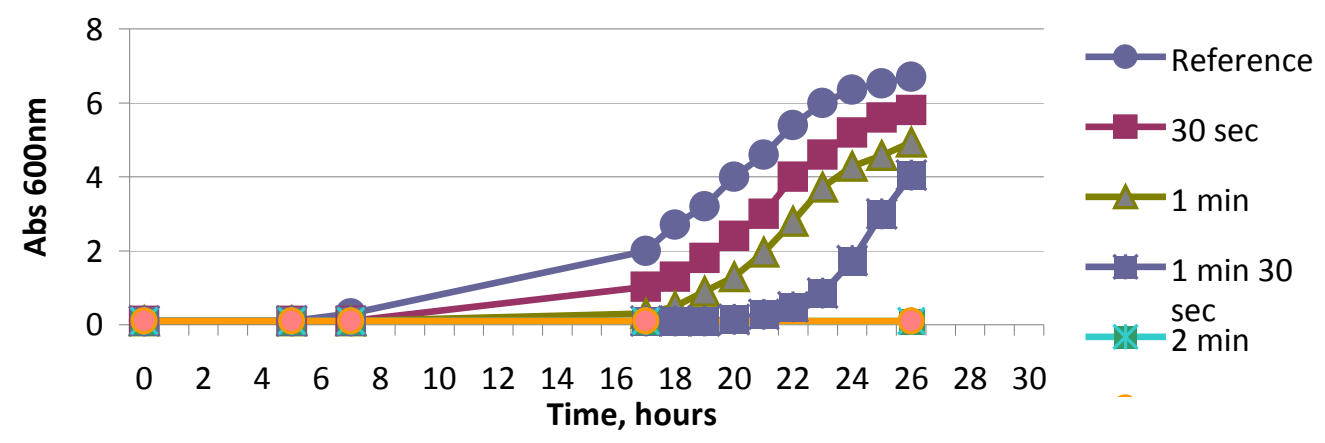

b)

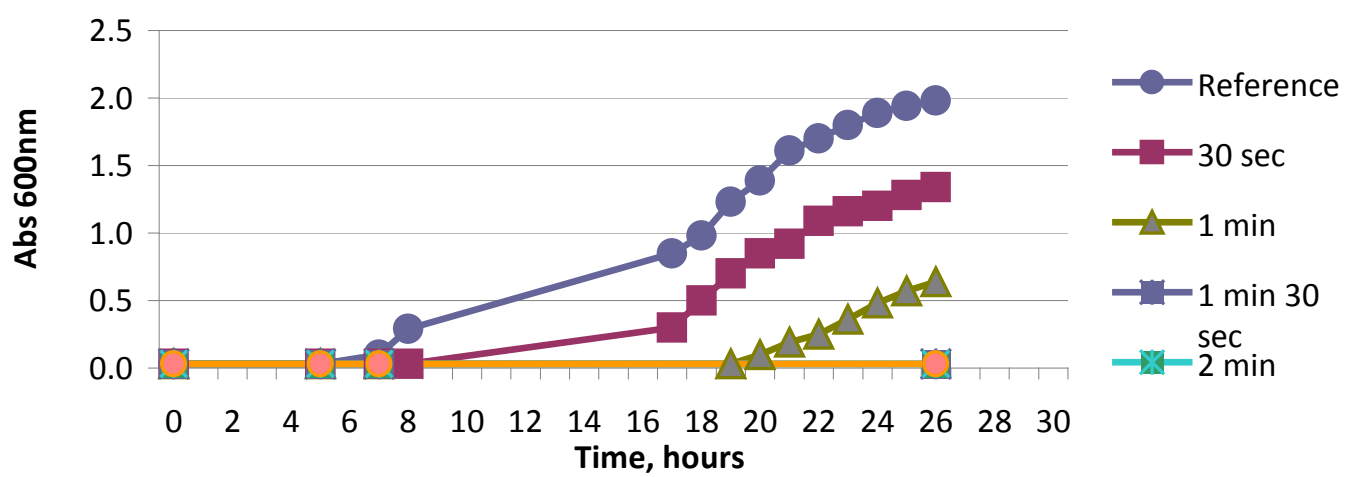

c)

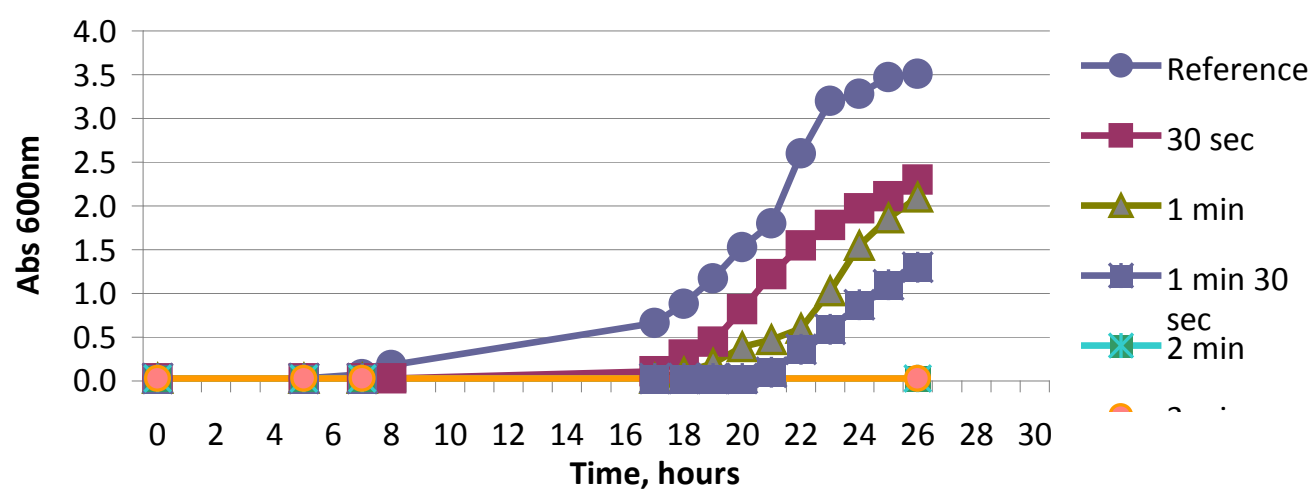

Fig. 1. Absorbance at $600 \mathrm{~nm}$ values in a) $E$. coli K12-MG 1655, b) $E$. faecalis ATCC 29212, c) $P$. aeruginosa ATCC 9027 cultures on orbital shaker after ozone treatment compared to untreated reference

The growth curves showed a characteristic appearance, with a lag phase of 6-8 hours for reference (untreated cultures) and longer lag phases, up to 16-18 hours for the cultures derived from the treated cells. This can be explained both by the lower number of survivors in ozonated samples and also by the cellular lesions that occur and are repaired in a longer time. For an ozonation time of more than 2 minutes, the cell damage was too great and could not be repaired. For all cases, the absorbance values were dependent of the ozonation time, and the lag phase was as long as the duration of treatment was greater.

Comparable results were obtained in the previous research on ozone use in water disinfection. Significant antimicrobial action was observed for $E$. coli and $S$. aureus after current air-liquid discharge plasma [8]. Xu et al., showed damaged bacterial outer structures, decreased concentration of cellular protein and nucleic acid after ROS treatment. In 2018, Wang H. et al. studied the effect of $\mathrm{O}_{3} / \mathrm{Cl}_{2}$ disinfection on opportunistic pathogens in drinking water distribution systems by the most 
probable number (MPN) method and demonstrated that ozone disinfection inactivated or damaged the bacterial cells due to its strong oxidizing properties [9]. In 2009, Lee Y. et al measured the total cell count (TCC) and intact cell count (ICT) by flow cytometry in order to evaluate the inactivation kinetics of bacteria in ozonated water, showing that the bacterial communities may have high and low ozone sensitivity [10].

Patil S. et al. studied the inactivation of E. coli in orange juice and showed that the applied gaseous ozone treatment resulted in a population reduction of $5 \log$ cycles [11].

\section{Conclusions}

1. The ozone treatment of water has considerable antimicrobial effect due to the ozone strong oxidizing properties.

2. The bacterial strains of of E.coli K12-MG 1655, E. faecalis ATCC 29212 and P. aeruginosa ATCC 9027 were sensitive to ozone treatment; the viability of cells decreased with 3 orders of magnitude after 30 seconds of ozonation and the effect became lethal after 1 minute.

3. The growth curves showed larger lag phases and lower numbers of cells, depending on the ozone treatment time.

\section{References}

[1] Crites R., Tchobanoglous G. Small and Decentralized Wastewater Management Systems. New York: The McGraw-Hill Companies, 1998.

[2] Nabi Bidhendi G.R., Hoveidi H., Jafari H.R. etc. Application of ozonation in drinking water disinfection based on an environmental management strategy approach using swot method. Iran J. Environ. Sci. Eng., vol. 3, 2006, pp. 23-30.

[3] Urs von Gunten. Ozonation of drinkingwater: Part II. Disinfection and by-product formation in presence of bromide, iodide or chlorine. Water Research. vol. 37, 2003, pp. 1469-1487.

[4] Smith D.J., Moss C.R. The development of ozone for potable water treatment within the United Kingdom. Ozone Sci. Eng., vol. 15, 1993, pp. 515-532.

[5] Rice R.G., Robson C.M., Miller G.W. etc. Use of ozone in drinking water treatment. J. Am. Water Works Assoc., vol. 73, 1981, pp. 44-57.

[6] Restaino L., Frampton E.W., Hemphill J.B. etc. Efficacy of ozonated water against food-related microorganisms. Appl. Environ. Microbiol., vol. 61, 1995, pp. 3471-3475.

[7] Prabakaran M., Selvi S.T., Merinal, S. etc. Effect of ozonation on pathogenic bacteria. Advances in Applied Science Research, vol. 3, 2012, pp. 299-302.

[8] Xu Z., Cheng C., Shen J. etc. In vitro antimicrobial effects and mechanisms of direct current airliquid discharge plasma on planktonic Staphylococcus aureus and Escherichia coli in liquids. Bioelectrochemistry, vol. 121, 2018, pp. 125-134.

[9] Wang H., Hu C., Zhang S. etc. Effects of O3/Cl2 disinfection on corrosion and opportunistic pathogens growth in drinking water distribution systems. Journal of Environmental Sciences. Available at: doi: https://doi.org/10.1016/j.jes.2018.01.009.

[10]Lee Y., Imminger S., Czekalski N. etc. Inactivation efficiency of Escherichia coli and autochthonous bacteria during ozonation of municipal wastewater effluents quantified with flow cytometry and adenosine tri-phosphate analyses. Water Research, vol. 101, 2016, pp. 617-627.

[11] Patil S., Bourke P., Frias M. etc. Inactivation of Escherichia coli in orange juice using ozone. Innovative Food Science \& Emerging Technologies, vol. 10, 2009, pp. 551-557. 